\title{
СОЦИАЛЬНО-ПЕДАГОГИЧЕСКАЯ КОРРЕКЦИЯ ПОВЕДЕНИЯ ДЕТЕЙ В УСЛОВИЯХ ПОВСЕДНЕВНОЙ ЖИЗНИ В ПРИЮТЕ
}

\author{
М.Г. Делиу \\ Московский гуманитарный университет
}

\begin{abstract}
Аннотация: В статье анализируется педагогическая коррекция детей в условиях повседневной жизни в приюте. Ставится задача коррекции (социально-психологическая, сочиально-педагогическая, сочиально-медиџинкая) и направления (психологическая коррекция, оздоровление и профилактика) реабилитации детей, попавщих в соичиальный приют.

Ключевые слова: сочиально-педагогическая коррекция, девиантное поведение, сочиальная среда, помощьь детям
\end{abstract}

\section{SOCIO-PEDAGOGICAL CORRECTION OF CHILDREN'S BEHAVIOR IN THE CONDITIONS OF EVERYDAY LIFE IN THE SHELTER}

\author{
M.G. Deliu \\ Moscow University for the Humanities
}

\begin{abstract}
The article analyzes the pedagogical correction of children in the conditions of everyday life in the shelter. The task of correction (socio-psychological, socio-pedagogical, socio-medical) and the direction (psychological correction, rehabilitation and prevention) of rehabilitation of children in a social shelter is set.
\end{abstract}

Keywords: Social and pedagogical correction, deviant behavior, social environment, help for children

Социально-педагогическая коррекция - это формирование определенных свойств личности ребенка, положительное влияние на его развитие, работу с отклонениями в поведении.

Основными задачами в коррекционной работе педагога в приюте являются профилактика девиантного поведения, снижение уровня личностной тревожности, формирование адекватных способов поведения в различных социальных ситуациях, как альтернатива агрессивному.

Социальная педагогическая коррекционная работа педагога в приюте заключается в том, чтобы защищать интересы ребенка и дать ему право на достойную жизнь, оказать социальную помощь, не откладывая. Социальный приют сотрудничает с государственными службами, с учреждениями образования и здравоохранения, со всеми, кому не безразлично детское воспитание. (Мухина, 2003: 15-30)

Главная цель каждого сотрудника, который играет важную роль в судьбе ребенка, выяснить какое состояние у ребенка в стенах приюта, поставить задачи, с помощью которых он пройдет социально педагогическую коррекцию. Сотрудники выясняют, какой дальнейший путь жизнеустройства ждет ребенка по выходу из приюта. 
Основная задача у педагогов - вернуть ребенка в семью, при условии, что в ней отсутствует рукоприкладство, жестокость и безразличие родителей. Дети, которые пережили жестокое обращение со стороны родителей, испытывают чувство страха перед ними и не желают их видеть. В такой ситуации после реабилитации детям дается право выбора вернуться в семью или остаться в приюте.

Как только дети поступают в приют, их проблемами начинают заниматься соответствующие службы: медицинская; психологическая; учебно-воспитательная; социально-правовая.

C ребенком каждый день работают, используя различные приемы воздействия (игровые программы, беседы). Это помогает собрать информацию о состоянии ребенка, помочь ему освоиться в стенах приюта. Через беседы и игры младшие школьники постепенно раскрываются, становятся более спокойными, раскрепощаются, усваивают правила и режим жизни приюта.

Как пишет А.Т. Шилова, для реализации социально-педагогической коррекции разрабатывается система занятий, которые имеют четкую структуру и включают упражнения на создание рабочей обстановки, упражнения по теме занятий, рефлексию (Шилова, 2004: 5-15).

Работа проводится поэтапно: на ориентировочном этапе ставится цель изменить стереотипы поведения, устранить неравенство, удовлетворить потребность в безопасности и принятии. На этом этапе необходимы следующие занятия: «Знакомство», «Ярмарка достоинств».

На первом занятия «Знакомство» при выполнении упражнения дети выбирают для себя любое животное. Коррекционный смысл в том, чтобы дети таким путем вышли из своего «Я», «надели на себя» другой образ-

В итоге дети называют себя теми животными, которые им нравятся за какието качества, которыми, как кажется, они сами не обладают. Собаки - верные и смелые, кошки - милые и грациозные, у лошадок - грива, а у птичек - крылышки. Поэтому такая игра может быть просто воплощением желания иметь что-то подобное. (Подласый, 2002: 45-69)

Второе занятие-«Ярмарка достоинств», на которой дети учатся преодолевать барьеры на пути самокритики, закрепляют навыки уверенного поведения, а также учатся самоанализу.

Подводя итоги занятий, младшие школьники отметили, что стали верить в себя, лучше узнали друг друга, им стало легче общаться, и они перестали враждовать между собой.

Следующим этапом социально-коррекционной работы по поведению младших школьников, стала индивидуальная работа. При работе с ребенком, имеющим высокий уровень тревожности, сверхчувствительность к негативному отношению к себе, проводилась работа со страхами: пластическое изображение 
страха, гнева. Неадекватная самооценка агрессивных детей, их негативное восприятие себя со стороны окружающих прорабатывалась средствами арттерапии: рисование собственного гнева.

Занятия по арт-терапии наиболее эффективны в работе педагогов, т.к. в ней отсутствуют какие-либо ограничения применении (возраст, пол, навыки ребенка), развивается внимание, собранность, а так же повышается самопознание и самовыражение. (Смирнова, 2004: 35-45)

Для социальных педагогов наиболее важно, облегчить адаптацию ребенка в новых условиях, дать возможность снять эмоциональное напряжение, исключить раздражители из его поля зрения, дать условия для оказания социальнопсихологической коррекции на основе индивидуальных программ социальной реабилитации.

На основе анализа научных исследований Л.С. Выготского и А.Р. Лурия (Выготский, Лурия, 1993: 359) выявлены следующие функции:

- Защита ребенка в его взаимоотношениях с родителями.

- Обеспечение безопасности каждого ребенка.

- Снятиепсихическогонапряжения,какследствиясоциально-психологического ограничения в семье.

- Диагностика искажения в личностном развитии и психофизическом состоянии, с целью разработки индивидуальной программы для социальной реабилитации;

- Восстановление и развитие важных форм человеческой жизнедеятельности, познания, труда и общения для успешной адаптации ребенка в социуме.

-Предоставление ему возможности освоить новые социальные роли.

Все функции и деятельность социально-педагогической коррекции направлены на создание социальных условий для детей, имеющих нарушения психологического состояния, физически ослабленных. Таким образом, в социальном приюте создаются условия для оказания социально-педагогической коррекции на основе индивидуальных программ для реабилитации. Коррекционная работа позволяет обеспечить детям правильное и гармоничное развитие личности, установить связь с индивидуальными вариантами личного развития.

\section{СПИСОК ЛИТЕРАТУРЫ}

Выготский Л.С., Лурия А.Р. (1993) Этюды по истории поведения: Обезьяна. Примитив. Ребенок. М.: Педагогика-Пресс. 224 с.

Мухина В.С. (2003) Детская психология. - СПб.: Владос. 368 с.

Подласый И.П. (2002) Курс лекций по коррекционной педагогике. М.:ВЛАДОС. 352 с.

Смирнова Т.П. (2004) Психологическая коррекция агрессивного поведения детей. Ростов-на-Дону: Феникс. 160 с. 
Шилова Т.А. (2004) Психодиагностика и коррекция детей с отклонениями в поведении. М.: Айрис-Дидактика. 176 с.

Делиу Михаела Геннадьевна - магистрант второго курса кафедры педагогики и психологии высшей школы Московского гуманитарного университета. Научный руководитель - профессор кафедры педагогики и психологии высшей школы Л.В. Романюк. Адрес: 111395, Россия, г. Москва, ул. Юности, д. 5. Тел.: +7(901)33917-65. Эл. адрес: deliu_96@mail.ru

Deliu Mihaela Gennadievna - Master's student of the Department of Pedagogy and Psychology of the Higher School of the Moscow Humanitarian University. Scientific adviser: Professor of the Department of Pedagogy and Psychology of Higher School L.V. Romanyuk. Address: 5 Yunosti str., Moscow, 111395, Russia. Tel.: +7(901)339-1765. Email address: deliu_96@mail.ru 